Community: volume 7, nomor 1, April 2021

p-ISSN: 2477-5746 e-ISSN: 2502-0544

\title{
The Development of the Constituent Social Class as Political Participation in Banda Aceh and Meulaboh
}

\author{
Reni Juliani ${ }^{1}$, Rena Juliana ${ }^{2}$, and Nurkhalis ${ }^{3}$ \\ ${ }^{I}$ Department of Communication, Teuku Umar University, Meulaboh, Aceh Province, Indonesia \\ ${ }^{2}$ Department of Sociology, Teuku Umar University, Meulaboh, Aceh Province, Indonesia \\ ${ }^{3}$ Department of Tarbiyah, STAIN Teungku Dirundeng, Meulaboh, Aceh Province, Indonesia \\ \{renijuliani, nurkhalis\}@utu.ac.id, renajuliana@staindirundeng.ac.id
}

\begin{abstract}
*
Indonesia adheres to a democratic system of government. Each citizen, on the basis of the choice of ordinary people, chooses free political participation and then changes their direction as a sympathizer. Today, the excitement of political participation in Indonesian society to spread on Aceh has been somewhat hurt because some people have changed the political climate to be bad. This is reflected in the previous political participation side by side to deliver rhetoric to reap the voice of the people, but it has become a competition for each other. The purpose of this study is to find out what types of political participation occurred in constituents in Banda Aceh and West Aceh and who are the actors or groups that weaken or strengthen political participation in the constituents. The research method used is a qualitative approach with informants consisting of key informants, subject informants and non-subject informants. Utilising Weberian theory of social action the results showed that the types of political participation in the constituents of Banda Aceh and West Aceh were very different and that sympathizers and political actors continued to strengthen and weaken the constituents. It is expected that this research will be a comparative study of the dynamics of policy in the Aceh region.
\end{abstract}

Keywords: Constituent Social Class, Political Participation, Banda Aceh, Meulaboh

\section{Introduction}

Power becomes the absolute prerequisite for implementing good and proper governance at regional, central and intergovernmental levels. In a country that has a democratic system like Indonesia, power in the broader sense must be understood as a meaning of that not only the political elite participates, but every citizen must contribute to it, including through political participation.

Political participation is a conscious activity of citizens, both individuals and groups of people, to participate in oneself and influence government policy (A.A Gatara\&Moh, 2007: 92). In general, political participation itself can be divided into various forms (Firmanzah, 2008: 119), namely, electoral activity, i.e. all activities 
directly or indirectly related to electoral voting, organizational activities that are activities in political organizations, and political discussions or demonstrations.

Tasks of political participation include participation in voting, participation in a closed or open campaign, conducting a series of actions to express ideas, giving ideas or criticism through demonstrations and walking on the street, writing opinions in printed form or sharing opinions status on social networking sites, conducting dialogues or debates on political issues and so on.

In further developments political participation can be distinguished in several ways, including: active political participation, passive political participation and apathetic political participation. Active political participation, as an activity in nature, influences the process of political input, such as petitions, demonstrations, contacts with government officials, active members or party officials, and the proposition of alternative political decisions. Passive political participation is an act that achieves policy outcomes such as compliance with laws, the payment of taxes, and the maintenance of orderly security. Meanwhile apathetic political participation is an act of doing nothing, of disagreeing, of paying taxes, of deliberately obeying the law (civil disobedience), of not participating in political campaigns, and of not becoming an active member of a political party (Setiadi \& Usman, 2013: 142).

Today, in the process that is taking place in the community, especially among the constituents (participants in democracy) in the Aceh region, a radically politically militant form of participation has emerged. A group of people, despite their high political awareness, only has very little confidence in the government, like the state of voters, who virtually becomes absent in the presidential election, the vice-president always comes from Javanese descent. Meanwhile, the practice of radical militants is also apparent in the nomadic political constituents. It shows that they will emphasize their focus on parties or leaders who can guarantee their group's capital or political interests.

The condition of radical militant political participation has negatively affected political participation activities and did not contribute to the establishment of good and proper governance in accordance with democratic systems and mechanisms.

\section{Literature Review}

\subsection{Political Participation}

The word participation comes from English and means taking part in activities together with others. Participation is a mental involvement or mental and emotional participation in the achievement of goals and the assumption of responsibility for the company concerned (Amrizal, etc, 2018:22)

Political participation can be defined as the activities of civil society members that meet the requirements of the law to align its voting rights on the election of 
Community: volume 7, nomor 1, April 2021

p-ISSN: 2477-5746 e-ISSN: 2502-0544

legitimate leaders or officials through free, direct, general and secret elections (Halim \& Muhlin, 2016: 71).

Political participation is the effort of the community to influence the political decision-making process, to determine political leaders and to develop a sense of responsibility in political life. Political participation is an important aspect of a democratic state order as it influences the legitimacy of society over governance.

Political participation is the spearhead of success in a democratic state order. Public participation in politics plays a very important role. The higher the participation, the better. This is because the high level of community involvement in politics illustrates their level of knowledge in political matters so that they participate in these activities (Budiardjo, 2008: 369).

Then the question arises as to why someone participates in the political process or participates less. Factors that are expected to influence a person's political participation are political awareness and trust in the government (political system). Political awareness means awareness of the rights and duties of citizens. This concerns the knowledge of the social and political environment as well as the interest and attention of the surrounding community and the political environment. What is meant by attitudes and confidence in the government, is the assessment of a person about the government: whether they can trust the government or can be influenced or not at all (Subakti, 2007: 144).

Based on the high and low of these two factors, Paige divides the participation into four types. When someone has a high level of political awareness and trust in the government, political participation is usually active. Conversely, if political awareness and confidence in the government are low, political participation tends to be passivedepressive (apathetic). The third type of involvement is radical fighters when political awareness is high but trust in the government is very low. If political awareness is very low, but trust in the government is very high, this involvement is called inactive or passive (Subakti, 2007: 144).

High and low political awareness and confidence of the government are in four ways, namely active participation, passive participation, apathetic participation and radical militant participation (Setiadi\& Usman, 2013: 154). In the meantime, various forms of political participation that occur in several countries can be distinguished conventionally and unconventionally, as well as legal (petition) or illegal (violent or revolutionary means).

Aceh's population was 72.28 percent or $2,414,801$ valid votes from $3,431,582$ voters at the 2017 Aceh gubernatorial election. The number of people participating in this political event in Aceh has declined compared to 2012. In 2012, the number of Acehnese exercising their voting rights was 75.73 percent. While for 2017, the target of total community participation is the expectation of the Aceh Independent Electoral Commission (KIP) of 75 percent (Afif, 2017). Ismail (2017) added that up to 57,536 or 
37.3 percent of the total number of permanent voters (Permanent Voter, DPT) from Banda Aceh, namely 151,105 people, in the regional elections for Mayor/ Deputy Mayor of Banda Aceh and Governor/ Deputy Governor of Aceh in 2017, did not exercise their voting rights.

In the election of the ruler in West Aceh, Bahagia Idris (Umar, 2017) mentioned that the chairman of the West Aceh KIP emerged from the results of the KIP's summing up that Ramli MS and Banta PutehSyam were in the lead with 52,538 votes. TeukuAlaidinsyah and Kamaruddin received 48,201 votes in the second highest position and 4,215 votes in the final position, Fuad Hadi and Muhammad Arief. In the 2017 elections to Regent Aceh Barat, a total of 104,954 votes were cast.

The simultaneous parliamentary elections in 2019 increased public participation in order to contribute to the Democratic Party. Agusni (Agse, 2019), commissioner of the Independent Electoral Commission (KIP), said the turnout in Aceh in the 2019 parliamentary elections exceeded the target. Voter turnout has increased significantly. The number of voters of Tanah Rencong is 79 percent. Compared to the 2014 elections, which reached only 72 percent.

\subsection{Political-Democratic Conflict}

Conflicts arise because each person differs both from ethnic elements and from interests, will, and life goals. The aggravation of differences and the clash of conflicts of interest caused by several factors. First, there are differences in the socio-political, economic and socio-cultural background that have a strong impact. Second, there are different thoughts. Third, there is an unsympathetic attitude towards a party, the system, and the mechanisms that exist in the organization. Fourth, there is a sense of dissatisfaction with the organizational environment, which, however, does not meet the wishes and when someone has to leave the group and take a big risk (Hidayat, 2009: 76).

Currently, identity politics has become an important part of the Democratic Party in Indonesia. This is because in the political sphere power is often taken over and maintained. The question of identity often becomes a shield and a reinforcement of political power to admit ethnic conflict, as each party chooses leaders in the name of tribal ethnicity and consciousness. Racist issues are very sensitive issues that can change the political map and support of political interests in any democracy. When identity policy is used as an instrument for achieving goals, especially in the interests of power, it becomes a threat to the unity and integrity of the nation. This is because the priority is leaders from the same ethnic or ethnic group and religion. This is certainly very dangerous for the diversity of Indonesia, which is endowed with a multitude of extraordinary potentials. In certain situations, there will certainly be conflicts between ethnic groups and religions that will allow the dynamics of Indonesian life to be influenced (Ramadhan, 2017: 37). 
Community: volume 7, nomor 1, April 2021

p-ISSN: 2477-5746 e-ISSN: 2502-0544

Democracy is a form of government in which all citizens, regardless of religion, gender and educational level, have the same decision-making rights that can change their lives. Democracy enables citizens to participate in the formulation, development and design of laws both directly and through representation (Bawazir, 2015: 79)

Talking about democracy means talking about power, or rather the civilized management of power. It is a power management system based on values and ethics and a civilization that respects human dignity. The long history of centralized and arbitrary practices in power management that stem from ancestors, military dominance, or other political oligarchies has encouraged humanity to strive for a human power management system. Authoritarian power becomes the enemy of humanity because the authorities do not only monopolize power, but also monopolize the truth. The truth belongs to the authorities, so disagreements are seen as criminal acts that must be punished by the state (Kristiadi, 2008: 3).

Adam Przeworski believes that the transition from authoritarianism to democracy is the result of negotiations between dominant groups that intend to secure and develop their interests. For him, political democracy is a democracy that, in addition to the socio-economic power they have built, protects the interests of the dominant group. Przeworski rejects the idea that class and economy are the social basis for determining political results. In addition, the determinants of the political results largely depend on the management of the leadership, the state of the political organizations and institutions formed in the transition process (Suyatno, 2008: 113).

In a democratic country, it is clear that all citizens have the fundamental right to implement their respective religious laws. However, the state does not have the power to control the religious rights of its citizens. It is entirely up to the individual freedom and religious community of the citizens concerned. If there are internal differences in understanding the Sharia in every religion. Even in the democratic principle, the state must be neutral towards religion and interpretations of religion. The constitution as a social document does not regulate matters of state authority over religion. Even the constitution does not make the state an instrument of religion or religion. In the constitution, religious rights are governed only generally in human rights (Deny, 2006: 34).

The above detailed explanation of the conflict also leads to the state of political conflict in society, especially during regional elections until the presidential elections. The escalation of political conflicts is becoming increasingly prevalent when sympathizers or loyal supporters execute the doctrine of power without understanding how to do democracy right. 
Community: volume 7, nomor 1, April 2021

p-ISSN: 2477-5746 e-ISSN: 2502-0544

\subsection{Max Weber's Theory of Social Action}

Weber begins the process of systematic conceptualization by setting up a classification of four types of action. It takes its starting point from the concept of rationality and the distinction of two different kinds of ultimate-end system and the corresponding relation of ultimate ends to the choice of mean. In the case of Wertrationalitatthe choice of means is oriented to the realization of a single absolute value without reference to considerations of cost. This type of action implies that the actor cannot judge whether the chosen method is most appropriate or better suited to achieve other goals, or by other expressions the final value for persons who are not rational, so alternatives are not considered. In that of Zwecrationalitat, on the other hand, it is oriented to a plurality of value in such a way that devotion to any one is limited by possibility of its entailing excessive cost in the form of sacrifice of the others. Instrumental rationality, that is, social actions performed by a person based on reasoning and conscious decisions about the purpose of the act and the availability of the instruments used to do so. By contrast with these rational types, he then formulates what are essentially two different residual categories. The one, the 'affectual' type, does not distinguish what may be called biologically inherited emotional tendencies from valueattitudes which are not formulated in logically determinate fashion, hence to involve in the rational types. The actions are deliberately shaped with emotional control and the darkness of the actor. In other words, actions are dominated by feelings or emotions without intellectual reflection or deliberate planning. The other category, 'traditional' action, is on quite a different level. It's of great significance to Weber's empirical research, but does not fit directly with the others in the same classification. The actions based on habits to do something in the past (Weber, 1947: 14).

\section{Method}

The research will answer questions about how the political participation of voters in the cities of Banda Aceh and Aceh Barat develops. This research is important because political participation and social class are closely linked to the forthcoming parliamentary elections, so that the mapping of new forms of political participation and new social class formation can be more accurately identified.The research used descriptive qualitative methods. Data were collected through in-depth interviews, which included a list of questions-answering the problem formulation of the research. In addition, data collection was supplemented by documentation in the form of secondary data; print media coverage or online media, info graphics and others. The technique of extracting whistle-blowers used the Purposive Sampling Technique, which consists of individuals serving as local politicians, political scientists, political experts, and civil society. 
Community: volume 7, nomor 1, April 2021

p-ISSN: 2477-5746 e-ISSN: 2502-0544

\section{Result and Discussion}

4.1. The Development of The Constituent Social Class as Political Participation in Banda Aceh And Meulaboh

\subsubsection{Increased Political Participation in Banda Aceh and Meulaboh}

The participation of Acehnese in the politics of Banda Aceh and Meulaboh in the parliamentary elections of 2019 has increased significantly compared to previous years. Almost all people are involved to cast their votes in this Democratic Party. This shows how much support the community providing for the future of Aceh and Indonesia.

The development of political participation in Aceh is now much better, and even if passive political participation in Aceh was the majority before, active political participation is more visible at this time. This shows that the political consciousness of the people in Aceh is much better. Although conflicts of interest in the political process in democracy in Aceh are inevitable.

The Independent Electoral Commission of Aceh (KIP) seeks to improve the situation of declining turnout in 2014 by conducting investigations to investigate the causes of the decline in Democratic Party turnout for the President and VicePresident in Aceh Province. Research conducted by KIP Aceh in collaboration with the Initiative Survey Network (JSI) identified several issues that led to a decline in participation rates, including a community mind-set that still believed that the community's choice would not benefit, a negative escalation of the campaigns and a black campaign that tends to make the community psychologically confused, voter participation, installation of information facilities such as billboards for remote villages, and the weak role of political parties in performing party functions that affect the lack of public participation in elections (KIP, 2016).

\subsubsection{Identity Politics Becomes a Weapon}

Past tendency that has become the background of a person or a group of people as voters to choose their future leaders based on the religion and ethnicity of future leaders.

Most informants in the research indicated that although the 2019 parliamentary elections were held concurrently in Aceh, especially in Banda Aceh and Meulaboh, the presidential election policy received more attention than the parliamentary elections. This time, there are some interesting things in the presidential elections. Both presidential candidates are familiar with Aceh and known by Aceh. Joko Widodo, or better known as Jokowi, lived in central Aceh, but only 19 percent of the votes Jokowi received differed significantly from Prabowo, who was the Special Forces Commander in Aceh, with 81 percent. 
From the point of view of the closeness between Jokowi and the people in Aceh, Jokowi should have a bigger voice than Prabowo. This has become a polemic that evolves in society. The question of Jokowi's identity with Chinese blood, etc. leads to Jokowi casting fewer votes than his opponent. In addition, the role of famous scholars such as Ustadz Abdul Somad, Ustadz Adi Hidayat, AA Gym, Alm $\mathrm{KH}$. Arifin Ilham, whose pioneer was the high priest Habib Rizieq, strengthened the influence of the Acehnese, who demonstrated their love for the Ulemas to follow the election of the Ulama. This is identity politics that Jakarta plays.

In Aceh itself, the identity policy is very strong and exists for a long time. Religious elements play an important role in politics in Aceh. During the Darul Islam/ Indonesian Islamic Army (DI/ TII), some regions are movements that describe the dynamics of religious identity that each group wishes to emphasize in order to express their religious identity. The Free Aceh Movement (GAM) is a group that aims to restore the Aceh region in harmony with Islam. The emergence of this movement, however, became a major conflict in Aceh and claimed many victims. That's because identity politics is based on religion.

Religious identity as a political force or instrument of its legitimacy on the basis of transcendent or divine dontrinal normativity. The divine idea of religious politics becomes symbols of political practices, structures and implementations. The religion of Islam, which for some followers is an integrated living system, has determined the existence of an Islamic state. The commitment to any teaching normativity places religious political groups in a decisive position. In this position, religious-political confrontation is often inevitable. In multi-religious countries, these events are common phenomena, although religion is not the only motivating factor and is always accompanied by other factors (Abdilah, 2001: 67-68).

Although Aceh is at peace now. Identity policy is still a color in every political arena. In every Aceh region, the Aceh Local Party is almost always superior to the existing national parties.

Aceh and Islam can not be separated. It is clear that identity politics in Aceh has been played in the parliamentary elections of 2019 in the name of religion. The racist problem, which should not have been addressed, was instead a weapon for potential leaders to become active throughout Indonesia. Although the parliamentary election is a democratic party that needs to be democratically celebrated. Democracy promotes human rights that must be neutral and that can not promote racism. Moreover, it is used as a means to pave the way for victory.

4.1.3. Max Weber's theory analyzes the reality of political participation in Banda Aceh and Meulaboh

Participation can mean support, because what is asked about political participation means support for politics. In general, political participation can be 
Community: volume 7, nomor 1, April 2021

p-ISSN: 2477-5746 e-ISSN: 2502-0544

interpreted as a person's involvement in the political process from the political stage to judging decisions, but it is also possible for someone to directly become a member of politics to oversee government policy. Participation is not only individual but can also be organized, peaceful and orderly.

Differences in social class in political participation arise from several factors, including: religion, culture, economics, political awareness and trust in government, education, with both political education promoting the growth of political maturity and the latter the factor of interest.

It is undeniable that the participation of radical fighters is also one of the categories of political participants in Banda Aceh and Meulaboh. This research also highlights the position of radical militant participation, even among graduates, so they have a high awareness of the importance of political participation, but have very little confidence in the government, which leads them not to vote.

The people of Aceh have no faith in the leadership of the legislative candidates and the president. The Acehnese observe the changes that have taken place in the country, and as a result, anyone who takes office will remain a banana salesman (if his job sells bananas). The banana seller has not noticed any significant changes after selecting certain candidates. It is different if the banana seller receives financial support in the form of a shopping cart, a packaging and marketing training, the product can get into the supermarket or there is an online trading system. They will develop and evolve. In the eyes of today's Acehnese, however, the promises of the campaign are only during the campaign. When political actors are elected, their fate as a conventional banana seller remains the same.

A high degree of understanding of political participation means that the Acehnese are intelligent and aware, except that there is greater distrust of the government. There are several factors that are causing the loss of confidence of radical militant government figures indicated by the informants, including: negligence and slowness in law enforcement, an economy that continues to decline, poverty and unemployment that will continue to be sustained.

Based on the theory of social action proposed by Max Weber, it can be demonstrated that the actions performed by Radical Militant Participation are considered value-oriented actions (Werktrational Action). This type of action says that the actor cannot calculate whether his actions are useful. They do not even consider the goals they have achieved. For them, the most important thing is that the actions they take are, in the opinion of the people, good and right.

\section{Conclusion}

The development of political participation in Banda Aceh and Meulaboh is characterized by the growing number of voters who take part in general elections. This high level of participation is undeniable because of the influence of identity politics that 
budding politicians use in their political campaigns. Different social classes of participation determine the great political commitment of 2019. Differences in the political participation of the social classes result from religious, economic, cultural, educational, consciousness and belief factors as well as interests that reduce the factor of trust in the government which occurs with radical militant participation due to several reasons, including bad laws, economic decline and increasing poverty and unemployment. Based on the results of the study, the researchers hope that the elections in Indonesia will not be confused with other topics, in particular the ethnicity, religion, and race questions. The researcher suggests to political actors not to use religious identity as the main theme of the campaign to minimize the division between religions in Indonesia. The researchers also advise the government to continue to disseminate smart policies to the public so that the community has more insight into good policies for the country.

\section{Bibliographies}

A, A. Gatara Said \&Moh. Dukikiah Said. 2007. Sosiologi Politik: Konsep dan Dinamika Perkembangan kajian. Bandung: Pustaka Setia.

Abdilah, S. Ubed. 2001. Politik Identitas Etnis: Penggulatan Tanda Tanpa Identitas. Magelang: Indonediatera.

Agse. 2019. EfekPemilu Serentak Partisipasi Pemilih di Aceh Lampaui Target.https://news.detik.com/berita/d-4548893/efek-pemilu-serentakpartisipasi-pemilih-di-aceh-lampaui-target.

Afif. 2017. Angka Partisipasi dalam Pilgub Aceh 72,28 Persen.https://www.merdeka.com/peristiwa/angka-partisipasi-dalam-pilgubaceh-7228persen.html.

Amrizal, Dedi, Ahmad Hidayah Dalimunthe \& Yusriati. 2018. Penanggulangan Golput dalam Pelaksanaan Pemilu Legislatif dan Pilkada. Medan: Lembaga Penelitian dan Penulisan Ilmiah Aqli.

Bawazir, Tohir. 2015. Jalan Tengah Demokrasi Antara Fundementalisme dan Sekularisme. Jakarta: Pustaka Al-Kautsar.

Deny J. A. 2006. Manuverelit, konflik, dan konservatisme politik. Yogyakarta: LKIS.

Firmanzah. 2008. Marketing Politik. Jakarta: Yayasan Obor Indonesia.

Halim, Rahmawati \& Muhlin Lalongan. 2016. Partisipasi Politik dan Masyarakat: Teori dan Praktik. Makassar: Sah Media. 
Community: volume 7, nomor 1, April 2021

p-ISSN: 2477-5746 e-ISSN: 2502-0544

Hidayat, Imam. 2009. Teori-teori Politik. Malang: Setara Press.

Ismail, Asnawi. 2017. Golput Banda Aceh Capai 57536 Orang. http://aceh.tribunnews.com/2017/02/22/gulput banda-aceh-capai-57536-orang.

KIP. 2016. KIP Aceh Launcingkan Hasil Riset Partisipasi Pemilih. https://kip.acehprov.go.id/kip-aceh-launcingkan-hasil-riset-partisipasi-pemilih/

Kristiadi, J. 2008. Demokrasi dan Etika Bernegara. Yogyakarta: Kanisius.

Ramadhan, Muhammad. 2017. Kontestasi Agama dan Politik: Menyemai Benih Kerukunan Antarumat Beragama Pasca konflik. Yogyakarta: LKIS.

Setiadi, Elly M \& Usman Kolip. 2013. Pengantar Sosilogi Politik. Jakarta: Kencana.

Subakti, Ramlan. 2007. Memahami Ilmu Politik. Jakarta: Grasindo.

Suyatno. 2008. Menjelajah Demokrasi. Bandung: Humaniora.

Umar, Raja. 2017. Hasil Rekapitulasi Suara di Aceh Barat, Calon Pertahanan Kalah. https://regional.kompas.com/read/2017/02/22/20231671/hasil.rekapitulasi.suara. di.aceh.barat.calon.petahana.kalah.

Weber, Max. 1947. The Theory of Social and Economic Organization. New York: Oxford University Press. 